\title{
THE STRUCTURAL ROLE OF EXCESS Cu AND Pb IN GLADITE AND KRUPKAITE BASED ON NEW REFINEMENTS OF THEIR STRUCTURE
}

\author{
DAN TOPA ${ }^{\S}$, EMIL MAKOVICKY ${ }^{\mathbb{I l}}$ AND TONČI BALIĆ-ŽUNIĆ \\ Geological Institute, University of Copenhagen, Øster Voldgade 10, DK-1350 Copenhagen K, Denmark
}

\begin{abstract}
Crystal structures of stoichiometric gladite (empirical formula $\mathrm{Cu}_{1.32} \mathrm{~Pb}_{1.37} \mathrm{Bi}_{6.65} \mathrm{~S}_{12.03}$ ) and krupkaite (empirical formula $\mathrm{Cu}_{2.00} \mathrm{~Pb}_{2.03} \mathrm{Bi}_{5.99} \mathrm{~S}_{12.04}$ ) from Felbertal, Austria, were refined to $\mathrm{R}_{1}=0.045$ and 0.037 , respectively, yielding improved positional parameters and interatomic distances. Structures of "oversubstituted" gladite with an excess of $\mathrm{Pb}+\mathrm{Cu}$ substitution for $\mathrm{Bi}+$ tetrahedral vacancy (empirical formula $\mathrm{Cu}_{1.55} \mathrm{~Pb}_{1.59} \mathrm{Bi}_{6.43} \mathrm{~S}_{12.02}$, percentage of the aikinite end-member, $n_{\text {aik }}=39$ ), of "undersubstituted" krupkaite $\left(\mathrm{Cu}_{1.85} \mathrm{~Pb}_{1.92} \mathrm{Bi}_{6.12} \mathrm{~S}_{12.06}, n_{\text {aik }}=47\right)$, and of "oversubstituted" krupkaite $\left(\mathrm{Cu}_{2.32} \mathrm{~Pb}_{2.40} \mathrm{Bi}_{5.64} \mathrm{~S}_{12.16}\right.$, $\left.n_{\text {aik }}=59\right)$ from the same locality, were refined to the $\mathrm{R}_{1}$ values of $0.041,0.051$, and 0.052 , respectively. Additional copper (occupancy 0.22 ) forms a broadly zig-zag pattern in each $1 \frac{1}{2}$ subcell of gladite. In "undersubstituted" krupkaite $\left(n_{\text {aik }}=47\right.$ ), the regular $\mathrm{Cu}$ position $(\mathrm{Cu} 1)$ was found to be slightly undersaturated. The "oversubstituted" krupkaite $\left(n_{\text {aik }}=59\right)$ contains additional $\mathrm{Cu}$, located in the $\mathrm{Cu} 2$ sites situated half-way between the fully occupied $\mathrm{Cu} 1$ positions. Fixing their occupancy to 0.18 , in agreement with EPMA data, and refining the adjacent large cation sites as two sites, with $0.18 \mathrm{~Pb}$ and $0.82 \mathrm{Bi}$, respectively, yielded the final model refined here. Interatomic distances and other characteristics of the polyhedra are used to evaluate the effects of cation substitution.
\end{abstract}

Keywords: gladite, krupkaite, oversubstitution, crystal structure, Felbertal, Austria.

\section{SOMMAIRE}

Nous avons affiné la structure cristalline de la gladite stoéchiométrique (formule empirique $\mathrm{Cu}_{1.32} \mathrm{~Pb}_{1.37} \mathrm{Bi}_{6.65} \mathrm{~S}_{12.03}$,) et de la krupkaïte (formule empirique $\mathrm{Cu}_{2.00} \mathrm{~Pb}_{2.03} \mathrm{Bi}_{5.99} \mathrm{~S}_{12.04}$ ) provenant de Felbertal, en Autriche, jusqu'à un résidu $\mathrm{R}_{1}$ égal à 0.045 et 0.037, respectivement, ce qui a mené à des paramètres de position et des distances entre atomes améliorés. Les structures de la gladite "sursubstituée", contenant un excédent de $\mathrm{Pb}+\mathrm{Cu}$ en substitution du $\mathrm{Bi}+$ lacune tétraédrique (formule empirique $\mathrm{Cu}_{1.55} \mathrm{~Pb}_{1.59} \mathrm{Bi}_{6.43} \mathrm{~S}_{12.02}$, pourcentage du pôle aikinite, $\left.n_{\text {aik }}=39\right)$, de la krupkaïte "sous-substituée" $\left(\mathrm{Cu}_{1.85} \mathrm{~Pb}_{1.92} \mathrm{Bi}_{6.12} \mathrm{~S}_{12.06}, n_{\text {aik }}=\right.$ $47)$, et de la krupkaïte "sursubstituée" $\left(\mathrm{Cu}_{2.32} \mathrm{~Pb}_{2.40} \mathrm{Bi}_{5.64} \mathrm{~S}_{12.16}, n_{\text {aik }}=59\right)$, provenant du même endroit, ont été affinées jusqu'à un résidu $\mathrm{R}_{1}$ de $0.041,0.051$, et 0.052 , respectivement. Des atomes additionnels de cuivre (taux d'occupation à ce site égal à 0.22 ) sont répartis grosso modo en forme de zig-zag dans chaque $1 \frac{1}{2} 2$ sous-maille de gladite. Dans la krupkaite "sous-substituée" $\left(n_{\text {aik }}\right.$ = 47), la position normale du $\mathrm{Cu}(\mathrm{Cu} 1)$ serait légèrement sous-saturée. En revanche, la krupkaïte "sursaturée" $\left(n_{\text {aik }}=59\right)$ contient des atomes additionnels de $\mathrm{Cu}$, situés aux sites $\mathrm{Cu}$ 2, à mi-chemin entre les sites $\mathrm{Cu} 1$, remplis. En fixant leur taux d'occupation à 0.18 , selon les données obtenues avec une microsonde électronique, et en affinant le site adjacent où logent les plus gros cations en supposant deux sites, avec $0.18 \mathrm{~Pb}$ et $0.82 \mathrm{Bi}$, respectivement, nous avons atteint le modèle final que nous décrivons ici. Les distances interatomiques et les autres caractéristiques des polyèdres servent à évaluer les effets de la substitution des cations.

(Traduit par la Rédaction)

Mots-clés: gladite, krupkaïte, sursubstitution, structure cristalline, Felbertal, Autriche.

$\S \quad$ Present address: Mineralogical Institute, University of Salzburg, Hellbrunnerstrasse 34/III, A-5020 Salzburg, Austria.

II E-mail address: emilm@geo.geol.ku.dk 


\section{INTRODUCTION}

The bismuthinite-aikinite $\left(\mathrm{Bi}_{2} \mathrm{~S}_{3}-\mathrm{CuPbBiS}{ }_{3}\right)$ family of ordered substitution derivatives ranks among the best researched families of natural complex sulfides (sulfosalts). In the order of increasing substitution of $\mathrm{Pb}$ $+\mathrm{Cu}$ for $\mathrm{Bi}+$ vacancy, distinct structures have been established for bismuthinite (Kupčik \& VeseláNováková 1970), pekoite, $\mathrm{CuPbBi}_{11} \mathrm{~S}_{18}$ (Mumme \& Watts 1976), gladite, $\mathrm{CuPbBi}_{5} \mathrm{~S}_{9}$ (Syneček \& Hybler 1974, Kohatsu \& Wuensch 1976), krupkaite, $\mathrm{CuPbBi}_{3} \mathrm{~S}_{6}$ (Syneček \& Hybler 1974, Mumme 1975), lindströmite, $\mathrm{Cu}_{3} \mathrm{~Pb}_{3} \mathrm{Bi}_{7} \mathrm{~S}_{15}$ (Horiuchi \& Wuensch 1977), hammarite, $\mathrm{Cu}_{2} \mathrm{~Pb}_{2} \mathrm{Bi}_{4} \mathrm{~S}_{9}$ (Horiuchi \& Wuensch 1976) and aikinite, $\mathrm{CuPbBiS}_{3}$ (Ohmasa \& Nowacki 1970a, b, Kohatsu \& Wuensch 1971).

Compositional ranges of individual members of this family were repeatedly investigated as well. A combination of electron-microprobe and single-crystal data was used in some of the above investigations, as well as by Harris \& Chen (1976), Žák et al. (1975), Chen et al. (1978; friedrichite) and Welin (1966). Investigations combining electron-microprobe data with powder diffraction were performed by Borodayev et al. (1970), electron microdiffraction was added by Mozgova et al. (1990); HRTEM was used by Pring (1989, 1995), whereas the latest, most extensive set of electron-microprobe data, unaccompanied by diffraction experiments, comes from Ciobanu \& Cook (2000).

The unusually rich spectrum of aikinite-bismuthinite derivatives from the deposit of Felbertal, Austria (Thalhammer et al. 1989), with a favorable mode of occurrence of single mineral grains or simple intergrowths in a quartz gangue, allowed us to perform single-crystal studies and crystal-structure determinations on a number of grains pre-analyzed with an electron microprobe. Compositional ranges of almost all derivatives mentioned above were tested, some spacegroup ambiguities resolved, and three new natural derivatives were found: a four-fold and a five-fold superstructure situated between gladite and krupkaite (Topa et al. 2000, Makovicky et al. 2001) and a new four-fold superstructure situated between krupkaite and aikinite (Balić-Žunić et al. 2002).

The present contribution concerns two minerals of the series, gladite (ideally $\mathrm{PbCuBi}_{5} \mathrm{~S}_{9}$ ) and krupkaite (ideally $\mathrm{PbCuBi}_{3} \mathrm{~S}_{6}$ ). Crystal-structure determinations on nearly ideal compositions have allowed us to further refine their structures. Structure determinations on both phases, oversubstituted (or undersubstituted) by $\mathrm{Cu}+$ $\mathrm{Pb}$ with respect to the ideal compositions, allow the direct establishment of the structural position of excess $\mathrm{Cu}$ (and $\mathrm{Pb}$ ) and a discussion of the nature of this "oversubstitution" in more than hypothetical terms. Previous determinations of the structure were performed for both phases by Syneček \& Hybler $(1974 ; \mathrm{R}=0.18$ and 0.25 , respectively, for krupkaite and gladite), for gladite by Kohatsu \& Wuensch $(1976 ; \mathrm{R}=0.14)$, and for krupkaite by Mumme (1975, $R=0.097)$. Our results will be contrasted with those of Pring (1989), obtained by HRTEM, who offered an alternative insight into substitutional models for the aikinite-bismuthinite series.

Throughout this study, the practical way of describing the compositions of the phases studied, proposed by Makovicky \& Makovicky (1978), will be adopted. All phases and structures will be treated as members of the composition series aikinite $(x)$ - bismuthinite $(100-x)$ or, in a short form, they will be characterized by $n_{\text {aik }}$ corresponding to the percentage of the $\mathrm{CuPbBiS}_{3}$ endmember in the $\mathrm{Bi}_{2} \mathrm{~S}_{3}-\mathrm{CuPbBiS}$ series. The value of $n_{\text {naik }}$ will be indicated in parentheses after the mineral name. Ideal gladite, $\mathrm{CuPbBi}_{5} \mathrm{~S}_{9}$, has $n_{\text {aik }}=33.33$, whereas ideal krupkaite, $\mathrm{CuPbBiS}$, has $n_{\text {aik }}=50.0$.

\section{EXPERIMENTAL}

The crystals examined come from the orebodies K3 and $\mathrm{K} 7$ of the Felbertal tungsten ore deposit (Topa et al. $2002)$. Gladite $\left(n_{\text {aik }}=34\right)$, oversubstituted gladite $\left(n_{\text {aik }}\right.$ $=39)$, undersubstituted krupkaite $\left(n_{\text {aik }}=47\right)$, and krupkaite $\left(n_{\text {aik }}=50\right)$ come from a copper-undersaturated assemblage from level 4 (1038 m above sea level) of the orebody K3. This assemblage also yielded two other members of the bismuthinite-aikinite series, salzburgite $\left(n_{\text {aik }}=40\right)$ (Topa et al. 2000$)$ and paarite $\left(n_{\text {aik }}=42\right)$ (Makovicky et al. 2001). Oversubstituted krupkaite occurs in the copper-saturated assemblage of the orebody K7 (level 6, $1100 \mathrm{~m}$ above sea level), in which emilite $\left(66<n_{\text {aik }}<68\right)$ (Balić-Žunić et al. 2002), hammarite and lindströmite are present as well.

The chemical composition of the crystals was obtained by electron-microprobe analysis before their extraction from polished sections. We used a JEOL-8600 electron microprobe equipped with Link EXL software with on-line ZAF correction. Analytical conditions employed were $25 \mathrm{kV}$ and $30 \mathrm{nA}$; synthetic and natural sulfide standards were used. The analytical results (wt.\%) and the resulting empirical formulae are summarized in Table 1.

All crystals studied have an irregular shape and are $0.02-0.10 \mathrm{~mm}$ in diameter (Table 2). They were measured on a Bruker AXS four-circle diffractometer equipped with CCD $1000 \mathrm{~K}$ area detector $(6.25 \mathrm{~cm} \times$ $6.25 \mathrm{~cm}$ active detection-area, $512 \times 512$ pixels) and a flat graphite monochromator using $\operatorname{MoK} \alpha$ radiation from a fine-focus sealed X-ray tube. Experimental and refinement data are summarized in Table 2. The SMART system of programs was used for unit-cell determination and data collection, SAINT+ for the calculation of integrated intensities, and SHELXTL for the structure solution and refinement (all Bruker AXS products). For the empirical absorption correction, based on reflection measurements at different azimuthal angles and measurements of equivalent reflections, program XPREP from SHELXTL package was used, and yielded merging $R_{I N T}$ factors (for equivalents) ranging from 
0.051 to 0.088 , compared to $0.10-0.21$ before the absorption correction (Table 2). The systematic absences were carefully checked, and space groups Pmcn and $P m c 2_{1}$ were respectively chosen as consistent with structures of the bismuthinite-aikinite family. The structures were solved by direct methods, which suggested a solution revealing the positions of $\mathrm{Bi}$ and $\mathrm{Pb}$ atoms together with principal $\mathrm{Cu}$ sites and the $\mathrm{S}$ atoms. In subsequent refinements, the positions of the remaining $\mathrm{Cu}$ sites with lower occupancies were deduced from the difference-Fourier syntheses.

In the final refinements, anisotropic temperature-factors were used for all the atoms except for the partly occupied $\mathrm{Cu}$ positions and the split $(\mathrm{Pb}, \mathrm{Bi})$ position in krupkaite $\left(n_{\text {aik }}=59\right)$. The refinements were stopped when the maximum shift/e.s.d. for varied parameters dropped below 1 . The results of the refinements are presented in Table 3, as well as in Figures 1-4, with interatomic distances in Table 4 (deposited). Structure factors may be obtained from the Depository of Unpublished Data, CISTI, National Research Council, Ottawa, Ontario K1A 0S2, Canada.

\section{Description of the STRUCtures}

\section{Principles of the structure}

The crystal structures of minerals of the bismuthinite-aikinite series are ordered superstructures of the crystal structure of bismuthinite, $\mathrm{Bi}_{2} \mathrm{~S}_{3}$. These superstructures are formed as a result of gradual, step-wise replacement of a half of the bismuth sites in the struc-

TABLE 1. COMPOSITION OF THE GLADITE AND KRUPKAITE CRYSTALS STUDIED, AS DETERMINED BY ELECTRON-MICROPROBE ANALYSIS

\begin{tabular}{|c|c|c|c|c|c|c|c|c|}
\hline wt. \% & Points & $\mathrm{Cu}$ & $\mathrm{Fe}$ & $\mathrm{Pb}$ & $\mathrm{Bi}$ & $\mathrm{Sb}$ & $\mathbf{S}$ & Total \\
\hline Gladite & 5 & $3.84(3)$ & $0.05(1)$ & $13.4(1)$ & $64.3(1)$ & 0.0 & $17.88(4)$ & $99.5(1)$ \\
\hline Gladite & 12 & $4.59(5)$ & 0.00 & $15.3(1)$ & $62.7(2)$ & 0.0 & $17.98(3)$ & $101.6(3)$ \\
\hline Krupkaite & 5 & $5.36(4)$ & 0.00 & $18.1(1)$ & $58.2(1)$ & $0.07(1)$ & $17.63(5)$ & $99.6(2)$ \\
\hline Krupkaite & 4 & $5.82(5)$ & 0.00 & $19.3(1)$ & $57.3(2)$ & $0.10(1)$ & $17.78(8)$ & $100.3(3)$ \\
\hline Krupkaite & 6 & $6.65(9)$ & 0.00 & $22.4(3)$ & $53.2(5)$ & 0.00 & $17.60(6)$ & $99.9(3)$ \\
\hline$a p f u$ & & $\mathrm{Cu}$ & $\mathrm{Pb}$ & $\mathrm{Bi}$ & $\mathbf{S}$ & $n_{\text {silk }}$ & $\Delta n_{\text {aik }}$ & $\mathrm{eV}$ \\
\hline Gladite & & 1.32 & 1.37 & 6.65 & 12.03 & 33.7 & 0.6 & -0.12 \\
\hline Gladite & & 1.55 & 1.59 & 6.43 & 12.02 & 39.2 & 0.5 & -0.04 \\
\hline Krupkaite & & 1.85 & 1.92 & 6.12 & 12.06 & 47.1 & 0.9 & -0.37 \\
\hline Krupkaite & & 2.00 & 2.03 & 5.99 & 12.04 & 50.3 & 0.4 & -0.25 \\
\hline Krupkaite & & 2.32 & 2.40 & 5.64 & 12.16 & 59.0 & 1.0 & -1.19 \\
\hline
\end{tabular}

The formula is based on a sum of cations in a bismuthinite-like subcell. $n_{\text {aik }}$ is the percentage of the aikinite end-member in the solid solution $\mathrm{Bi}_{2} \mathrm{~S}_{3}-\mathrm{CuPbBiS}$ calculated as $n_{\text {aik }}=12.5(x+y)$ for the empirical formula $\mathrm{Cu}_{x} \mathrm{~Pb}_{y} \mathrm{Bi}_{8-(x+y) 2} \mathrm{~S}_{12}(x \approx y)$ (Makovicky \& Makovicky 1978). $\Delta n_{\text {aik }}$ is equal to $|12.5(y-x)|$; eV is a chargebalance error per formula unit (pfiu) ture by lead. Parallel to this replacement is the filling of adjacent tetrahedrally coordinated sites by copper, resulting in the scheme $\mathrm{Bi}^{3+}+$ "tetrahedral vacancy" $\rightarrow$ $\mathrm{Pb}^{2+}+\mathrm{Cu}^{+}$(Figs. 1, 2).

The crystal structure of bismuthinite and of its derivatives consists of tightly bonded ribbons $\mathrm{Me}_{4} \mathrm{~S}_{6}$ that accommodate two distinct cation sites, the apical Bi site (denoted as Bi 1 in bismuthinite) and the central (inner) $M e ~ 2$ site. It is the latter site where the gradual replacement of $\mathrm{Bi} 2$ by $\mathrm{Pb}$ can proceed. Ribbons are arranged in a herring-bone pattern, the apical portions of one ribbon facing the central portion of the adjacent ribbon via the (empty) tetrahedral void.

Inside the ribbon, cations have a distorted square pyramidal coordination, which can be described in the case of $\mathrm{Bi}$ as $\mathrm{MeS}_{3+2}$. Full coordination polyhedra of both Bi 1 and $M e 2$ sites have a coordination number (CN) equal to 7, i.e., $\mathrm{MeS}_{3+2+2}$. Both polyhedra are monocapped trigonal coordination prisms that involve sulfur atoms from adjacent ribbons. They are oriented at $90^{\circ}$ and $0^{\circ}$, respectively, to the 4 - $\AA$-long $a$ axis. These coordination prisms incorporate the lone-electron pairs of $\mathrm{Bi}$ and $\mathrm{Pb}$ in their prismatic portions. Thus the loneelectron pairs are all concentrated in the spaces between the ribbons, contributing to the good cleavage of these minerals.

In the structures examined, either unsubstituted "bismuthinite-like ribbons" $\mathrm{Bi}_{4} \mathrm{~S}_{6}$, or half-substituted "krupkaite-like ribbons" $\mathrm{CuPbBi}_{3} \mathrm{~S}_{6}$ are the principal components, and are combined in them, in an ordered fashion, in different proportions. Oversubstituted krupkaite will also contain a small percentage of "aikinite-like ribbons" with both $\mathrm{Me} 2$ sites substituted by $\mathrm{Pb}$, resulting in the ideal composition $\mathrm{Cu}_{2} \mathrm{~Pb}_{2} \mathrm{Bi}_{2} \mathrm{~S}_{6}$ for the ribbon.

The site notation adopted for oversubstituted phases (Figs. 1,2) follows that used for stoichiometric phases; the additional cation sites are denoted as $\mathrm{Cu} 2$ in both structures. Therefore, no separate figures with site labeling are introduced for unsubstituted gladite and krupkaite.

\section{The stoichiometric phases}

The crystal structure of gladite $\left(n_{\text {aik }}=33.7\right)$ refined to $\mathrm{R}_{1}=0.045$ in space group Pmcn; it thus confirms that derived by Syneček \& Hybler (1974) and Kohatsu \& Wuensch (1976). It contains only one $\mathrm{Cu}$ and one $\mathrm{Pb}$ position (Fig. 3a), these being concentrated in four "krupkaite-like ribbons" $\mathrm{CuPbBi}_{3} \mathrm{~S}_{6}$ (Ohmasa \& Nowacki 1970a, Mumme et al. 1976) in the unit cell. Two additional "bismuthinite-like ribbons" $\mathrm{Bi}_{4} \mathrm{~S}_{6}$ centered on $y=0, z=0$ and $y=0.5, z=0.5$, complete the picture. The $\mathrm{Cu}$ atoms are concentrated along two (010) planes, at $y=0.25$ and 0.75 , respectively, with $\mathrm{Cu}$-free interspaces that are $1 \frac{1 / 2}{2}$ bismuthinite-like subcells wide. Any [010] row of en échelon $\mathrm{Me}_{4} \mathrm{~S}_{6}$ ribbons has the sequence krupkaite-krupkaite-bismuthinite, with the 
$\mathrm{Pb}$-substituted part of the krupkaite-like ribbons oriented toward the bismuthinite-like ribbon.

The crystal structure of krupkaite $\left(n_{\text {aik }}=50.3\right)$ refined to $\mathrm{R}_{1}=0.037$ in space group $P m c 2_{1}$; it thus agrees in principle with the results obtained by Syneček \& Hybler (1974) and Mumme (1975). It again contains only one kind of $\mathrm{Cu}$ and $\mathrm{Pb}$ atoms, exclusively in krupkaite-like ribbons (Fig. 3b). The $\mathrm{Cu}$ atoms are concentrated along (010) planes at $y=0.5$, a full $11 \AA ̊$ cell width apart, the site occupancy being equal to 1.0. The alternative $\mathrm{Cu}$ positions at $y=0$ were found to be empty, contrary to the findings of Mumme (1975), who found $0.2 \mathrm{Cu}$ in these and only 0.8 in the former sites.

\section{The non-stoichiometric phases}

The "oversubstituted" gladite $\left(n_{\text {aik }}=39.2\right)$ was refined to $\mathrm{R}_{1}=0.041$ in the same space group as the stoichiometric compound, Pmcn. Atom positions differ insignificantly from those in the stoichiometric phase. Besides the fully occupied $\mathrm{Cu} 1$ position, identical to that in the stoichiometric phase, a new partly occupied position, $\mathrm{Cu}$ 2, was found (Figs. 1, 4a). Its occupancy has been refined to 0.223 , indicating the chemical formula $\mathrm{Cu}_{4.89} \mathrm{~Pb}_{4.89} \mathrm{Bi}_{19.11} \mathrm{~S}_{36}$, close to the empirical microprobe-established composition, $\mathrm{Cu}_{4.65} \mathrm{~Pb}_{4.77} \mathrm{Bi}_{19.29}$ $\mathrm{S}_{36.06}$ (the latter suggesting $\mathrm{Cu} 2$ occupancy based on the $n_{\text {aik }}$ value in Table 1, equal to 0.178 ). The correlation coefficient between the site occupancy of $\mathrm{Cu} 2$ and its isotropic displacement factor (Table 3 ) is below 0.5 . $\mathrm{Cu} 2$ forms a broadly zig-zag pattern in every $1 \frac{1}{2}$ subcell interval situated between the (010) planes fully occupied by $\mathrm{Cu} 1$. This distribution corresponds entirely to the distribution of $\mathrm{Cu} 4$ and $\mathrm{Cu} 5$ (site occupancy 0.1) in the same type of intervals in the structure of salzburgite $\mathrm{Cu}_{1.6} \mathrm{~Pb}_{1.6} \mathrm{Bi}_{6.4} \mathrm{~S}_{12}$ (Topa et al. 2000). In both cases, the "krupkaite-like" ribbons statistically acquire an "aikinite-like" character, whereas the "bismuthinitelike" ribbons remain unchanged.

The "undersubstituted" krupkaite $\left(n_{\text {aik }}=47.1\right)$ yielded only one $\mathrm{Cu}$ and one $\mathrm{Pb}$ position (Table 3). Our attempts to refine the occupancy of the slightly deficient $\mathrm{Cu}$ site showed that the correlation between the site occupancy and temperature factors (0.54) precludes significant results. With both variables free to refine, the occupancy refined to 1.00 , whereas for the refinement

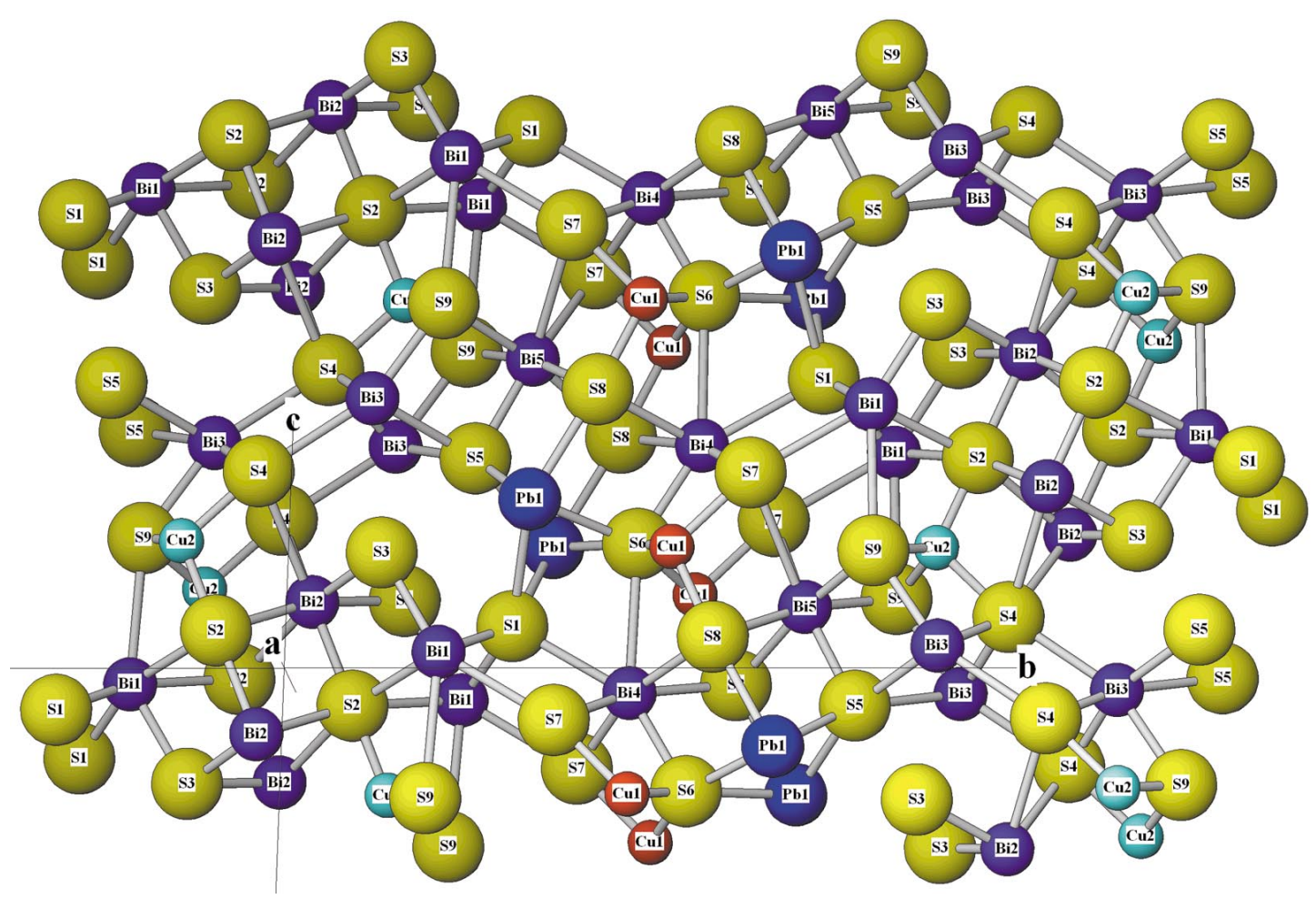

FIG. 1. A part of the crystal structure of oversubstituted gladite $\left(n_{\text {aik }}=39\right)$ with the atom coordinations and atom labels. The lengths and directions of the half-axes are indicated. Color code: fully occupied $\mathrm{Cu}$ positions: red, partially occupied positions (22.3\% occupancy): turquoise. 
of the anisotropic temperature-factor, the equivalent isotropic temperature-factor $U_{\text {eq }}$ was $0.044\left(\mathrm{R}_{1}=0.051\right)$. When the occupancy was fixed to the microprobe-determined value of 0.940 , the equivalent isotropic temperature-factor dropped for the anisotropic refinement to 0.0408 . On the contrary, for an isotropic temperaturefactor fixed to 0.042 (a compromise value between the above refinements), the occupancy of the $\mathrm{Cu}$ site refined to 0.975 ; this refinement is reported in Table 3 . The $R_{1}$ value remains constant for all these variations within the bounds of $\Delta \mathrm{R}_{1}=0.0001$.

Atom coordinates were practically identical in all the refinements attempted $\left(\Delta x_{\mathrm{i}} \approx 0.0001\right)$ and equal to those of krupkaite $\left(n_{\text {aik }}=50\right)$.

The "oversubstituted krupkaite" ( $\left.n_{\text {aik }}=59.0\right)$ lies at the upper end of the composition range of krupkaite, next to the composition of lindströmite $\left(n_{\text {aik }}=60\right)$ (Horiuchi \& Wuensch 1977, Topa et al., in prep.). It has two copper sites: $\mathrm{Cu} 1$, which was refined as fully occupied, and $\mathrm{Cu} 2$, a partly occupied site situated halfway between the $(010)$ planes occupied by $\mathrm{Cu} 1$ (Figs. $2,4 \mathrm{~b}$ ). The $\mathrm{Cu} 2$ site shows very high correlation (coefficient $=0.90$ ) between the site occupancy and the temperature factor; a free refinement converges to an occupancy of about 0.073 with $U_{\text {iso }}=0.001$, to be compared with $U_{\text {eq }}=0.042$ for the fully occupied $\mathrm{Cu} 1$ position. When the latter value is used and kept fixed for $\mathrm{Cu} 2$, the refined occupancy is 0.123 , yielding $2.246 \mathrm{Cu}$ apfu; when the microprobe data are used to fix the occupancy of the $\mathrm{Cu} 2$ site at $0.18 \mathrm{apfu}$, its $U_{\text {iso }}$ refines as 0.0498. In the same refinement, the $\mathrm{Bi} 3$ site was split into separate $\mathrm{Bi}$ and $\mathrm{Pb}$ positions, with occupancies fixed to 0.82 and 0.18 , respectively. These positions were refined with free coordinates and isotropic displacement factors (Table 3, footnote). For all these cases, $\mathrm{R}_{1}$ is equal to 0.052 . As illustrated in Table $3, U_{\text {eq }}$ for $\mathrm{Bi}$ atoms lies at $0.035-0.036$ except for $\mathrm{Bi} 3$ (0.045), i.e., for the site of partial $\mathrm{Pb}$-for-Bi exchange connected with the partially occupied $\mathrm{Cu} 2$ site. The atom coordinates are virtually identical for all these models, variations taking place on the fourth decimal place.

\section{Coordination polyhedra}

The precisely refined structures described in this study allow us to calculate improved data for the interatomic distances, bond angles and polyhedron characteristics for the cations involved (Tables 4-6). New

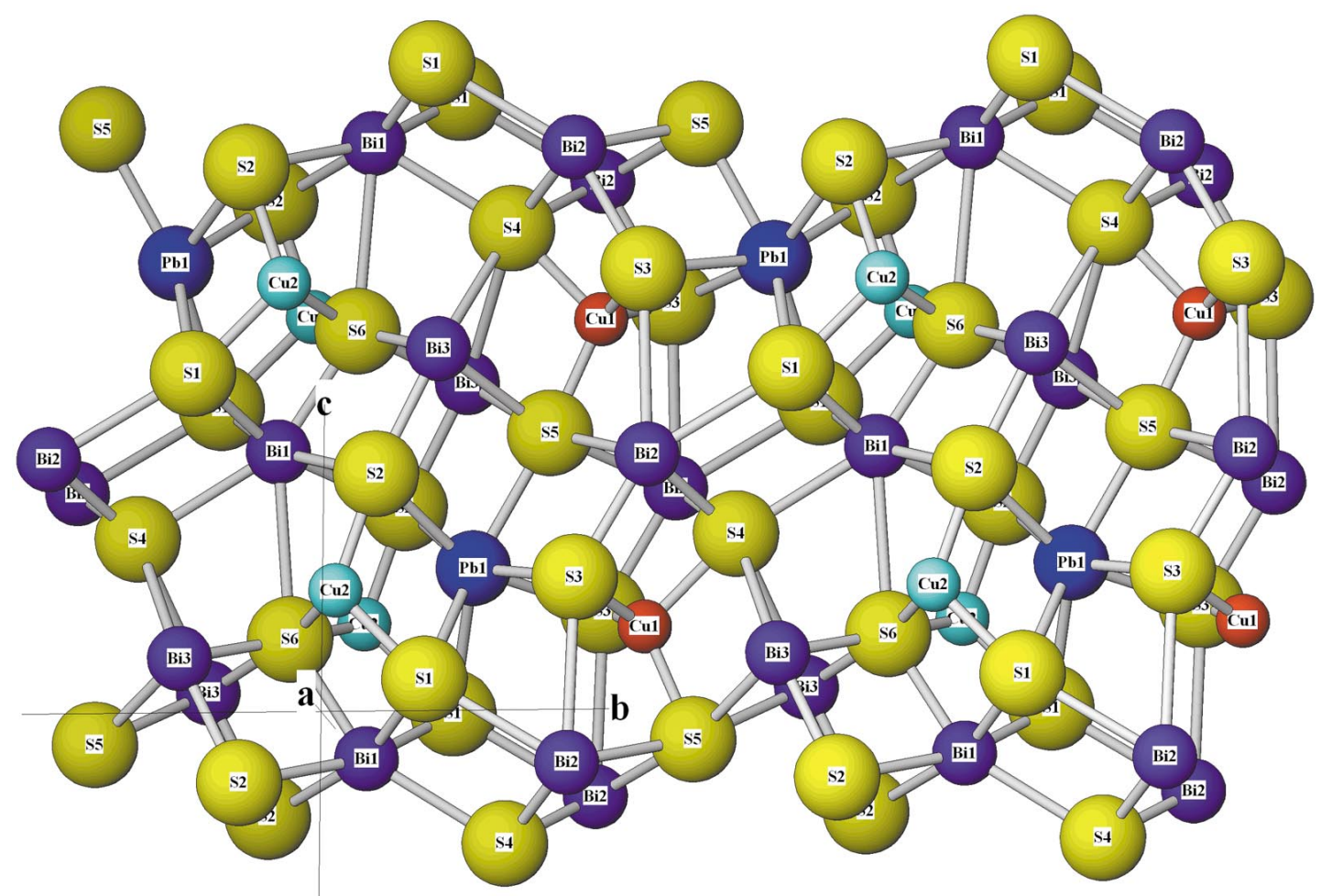

FIG. 2. A part of the crystal structure of oversubstituted krupkaite $\left(n_{\text {aik }}=59\right)$. Fully occupied Cu positions are indicated in red, partly occupied ones ( $12 \%$ occupancy) in turquoise. 
TABLE 2. INFORMATION ABOUT THE GLADITE AND KRUPKAITE CRYSTALS SELECTED, DETAILS ABOUT THE COLLECTION OF DATA, AND THE REFINEMENT PROCEDURE

\begin{tabular}{|c|c|c|c|c|c|}
\hline Sample label & bd33 & bd 39 & bd47 & bd50 & bd59 \\
\hline \multicolumn{6}{|c|}{ Crystal data } \\
\hline $\begin{array}{l}\text { Structural formula } \\
\text { Chemical form. wt }\end{array}$ & $\begin{array}{l}\mathrm{Cu}_{1.33} \mathrm{~Pb}_{1.33} \mathrm{Bi}_{6.67} \mathrm{~S}_{12} \\
2138.69\end{array}$ & $\begin{array}{l}\mathrm{Cu}_{1.63} \mathrm{~Pb}_{1.63} \mathrm{Bi}_{6.37} \mathrm{~S}_{12} \\
2157.27\end{array}$ & $\begin{array}{l}\mathrm{Cu}_{1.95} \mathrm{~Pb}_{1.95} \mathrm{Bi}_{6.05} \mathrm{~S}_{12} \\
2172.65\end{array}$ & $\begin{array}{l}\mathrm{Cu}_{2.00} \mathrm{~Pb}_{2.00} \mathrm{Bi}_{6.00} \mathrm{~S}_{12} \\
2180.06\end{array}$ & $\begin{array}{l}\mathrm{Cu}_{2.25} \mathrm{~Pb}_{2.25} \mathrm{Bi}_{5.75} \mathrm{~S}_{12} \\
2202.29\end{array}$ \\
\hline Space group & Pmcn & Pmcn & $P m c 2_{1}$ & $P m c 2_{1}$ & $P m c 2_{1}$ \\
\hline$a(\AA)$ & $4.0044(4)$ & $4.0100(3)$ & $4.0134(4)$ & $4.0145(4)$ & $4.0212(5)$ \\
\hline$b(\AA)$ & $33.575(3)$ & $33.589(3)$ & $11.208(1)$ & $11.202(1)$ & $11.232(1)$ \\
\hline$c(\AA)$ & $11.480(1)$ & $11.502(1)$ & $11.560(1)$ & $11.560(1)$ & $11.581(1)$ \\
\hline$V(\AA)$ & $1543.4(2)$ & $1549.2(2)$ & $520.0(1)$ & $519.9(1)$ & $523.1(1)$ \\
\hline$Z$ & 3 & 3 & 1 & 1 & 1 \\
\hline$D_{x}\left(\mathrm{Mg} \mathrm{m}^{-3}\right)$ & 6.903 & 6.925 & 6.938 & 6.963 & 6.991 \\
\hline \multicolumn{6}{|l|}{ No. of reflexions } \\
\hline for cell param. & 3516 & 4134 & 2790 & 2177 & 2255 \\
\hline$\mu\left(\mathrm{mm}^{-1}\right)$ & 70.198 & 70.089 & 69.799 & 69.889 & 69.685 \\
\hline$F(000)$ & 2680 & 2700 & 909 & 912 & 922 \\
\hline Crystal size (mm) & $0.08 \times 0.05 \times 0.04$ & $0.08 \times 0.04 \times 0.02$ & $0.08 \times 0.054 \times 0.036$ & $0.10 \times 0.07 \times 0.03$ & $0.08 \times 0.05 \times 0.03$ \\
\hline
\end{tabular}

\section{Data collection}

\begin{tabular}{|c|c|c|c|c|c|}
\hline $\begin{array}{c}\text { Detector-sample } \\
\text { distance (mm) }\end{array}$ & 60 & 60 & 40 & 60 & 60 \\
\hline Number of frames & 2080 & 2080 & 2600 & 2080 & 2080 \\
\hline Width of frames $\left({ }^{\circ}\right)$ & 0.25 & 0.25 & 0.20 & 0.25 & 0.25 \\
\hline Measurement time & & & & & \\
\hline (s)/frame & 60 & 60 & 45 & 30 & 60 \\
\hline Min. transmission & 0.00123 & 0.00339 & 0.00165 & 0.00316 & 0.00138 \\
\hline Max. transmission & 0.01335 & 0.01892 & 0.02022 & 0.02073 & 0.01651 \\
\hline No. of measured & & & & & \\
\hline reflections & 8856 & 8954 & 5299 & 3075 & 3140 \\
\hline No. of unique refl. & 1745 & 1800 & 1760 & 1176 & 1154 \\
\hline No. of observed & & & & & \\
\hline refl. $\left(\mathrm{I}>2 \sigma_{1}\right)$ & 1444 & 1566 & 1625 & 1133 & 1123 \\
\hline $\mathbf{R}_{\text {int }}$ & 0.0596 & 0.0548 & 0.0767 & 0.0652 & 0.0783 \\
\hline$R(\sigma)$ & 0.0330 & 0.0308 & 0.0589 & 0.0517 & 0.0512 \\
\hline$\theta_{\min }\left({ }^{\circ}\right)$ & 3.60 & 3.51 & 4.04 & 3.64 & 3.52 \\
\hline$\theta_{\max }\left({ }^{\circ}\right)$ & 26.86 & 26.92 & 30.49 & 26.77 & 26.78 \\
\hline Range of $h, k, l$ & $-4 \leq h \leq 3$ & $-4 \leq h \leq 5$ & $-5 \leq h \leq 5$ & $-4 \leq h \leq 5$ & $-4 \leq h \leq 5$ \\
\hline & $-40 \leq k \leq 41$ & $-40 \leq k \leq 41$ & $-15 \leq k \leq 16$ & $-13 \leq k \leq 13$ & $-13 \leq k \leq 12$ \\
\hline & $-13 \leq l \leq 14$ & $-14 \leq l \leq 13$ & $-16 \leq l \leq 16$ & $-14 \leq l \leq 14$ & $-14 \leq l \leq 14$ \\
\hline Coverage & & & & & \\
\hline (to $\theta$ max.) & $91.8 \%$ & $94 \%$ & $99.3 \%$ & $95.8 \%$ & $95.4 \%$ \\
\hline & & Refinem & $\mathrm{F}^{2}$ against all re & & \\
\hline$R\left(\mathrm{Fo}>4 \sigma_{\mathrm{Fo}}\right)$ & 0.0454 & 0.0405 & 0.0508 & 0.0373 & $0.0519^{* *}$ \\
\hline$R_{\text {all }}$ & 0.0530 & 0.0464 & 0.0535 & 0.0387 & 0.0525 \\
\hline$w R\left(\mathrm{Fo}>4 \sigma_{\mathrm{Fo}}\right)$ & 0.1091 & 0.1029 & 0.1185 & 0.0925 & 1386 \\
\hline$w R_{\text {all }}$ & 0.1135 & 0.1064 & 0.1197 & 0.0933 & 1392 \\
\hline Goof & 0.992 & 1.111 & 1.058 & 1.084 & 1.123 \\
\hline $\begin{array}{l}\text { No. of refl. } \\
\text { used }\end{array}$ & 1745 & 1800 & 770 & 1176 & 1154 \\
\hline No. of parameters & 98 & 101 & 64 & 67 & 70 \\
\hline No. of restraints & 0 & 0 & 1 & 1 & 1 \\
\hline${ }^{*}$ Weight. scheme & & & & & \\
\hline factors: $a, b$ & 0.08210 .0 & 0.06782 .0139 & 0.08010 .0 & $0.0593 \quad 0.0$ & 0.09922 .3094 \\
\hline$(\Delta \rho)_{\max }\left(\mathrm{e} \AA^{-3}\right)$ & 2.70 & 4.03 & 4.17 & 2.15 & 3.61 \\
\hline$(\Delta \rho)_{\min }\left(\mathrm{e} \AA^{-3}\right)$ & -2.73 & -4.21 & -2.15 & -3.02 & -3.27 \\
\hline scale factor & 0.03560 & 0.03245 & 0.06787 & 0.06822 & 0.07825 \\
\hline Extinction coeff. & 0.000025 & $0.00003(5)$ & - & - & - \\
\hline
\end{tabular}

${ }^{*} \mathrm{w}=1 /\left[\sigma_{\mathrm{Fo}}^{2}+(\mathrm{a} \cdot \mathrm{P})^{2}+\mathrm{bP}\right]$, where $\mathrm{P}=\left(\mathrm{Fo}^{2}+2 \mathrm{Fc}^{2}\right) / 3$. ** for a refinement with unsplit $(\mathrm{Bi}, \mathrm{Pb}) 3$ positions. bd: bismuthinite derivative 
structure refinements for $\mathrm{Bi}_{2} \mathrm{~S}_{3}$ (Lundgaard et al., in prep.) and $\mathrm{CuPbBiS}_{3}$ (Topa et al., in prep.) will be used for comparison. The following site-notation is used (Figs. 1, 2): In the refined structure of gladite, Bi 1 is the terminal and $\mathrm{Bi} 2$ the central coordination-polyhedron of bismuth in the "bismuthinite-like" ribbon. Bi 3 and $\mathrm{Bi} 4$ are the terminal polyhedra, whereas $\mathrm{Bi} 5$ and $\mathrm{Pb} 1$ are the "central" polyhedra of "krupkaite-like" ribbons. $\mathrm{Bi} 3$ and $\mathrm{Bi} 5$ are on one side of the ribbon, whereas $\mathrm{Bi} 4$ and the $\mathrm{Pb}$ site are on the other side of the ribbon. $\mathrm{Cu} 1$ is associated with $\mathrm{Pb} 1$, whereas $\mathrm{Cu} 2$ in gladite $\left(n_{\text {aik }}=39\right)$ is linked to the mixed $(\mathrm{Bi}, \mathrm{Pb}) 5$ position (Fig. 1). In all the refined structures of krupkaite, Bi 1 and $\mathrm{Bi} 2$ denote terminal coordination-polyhedra of bismuth, whereas $\mathrm{Pb} 1$ and $\mathrm{Bi} 3$ (with respect to the split positions $\mathrm{Bi} 3$ and $\mathrm{Pb} 2$ ) are the central polyhedra of the $\mathrm{Me}_{4} \mathrm{~S}_{6}$ ribbons. $\mathrm{Bi} 2$ is marginal to $\mathrm{Pb} 1$ and adjacent to the filled $\mathrm{Cu} 1$ tetrahedron. Bi 1 and $\mathrm{Bi} 3$ represent the "bismuth side" of the krupkaite-like ribbon (Fig. 2).
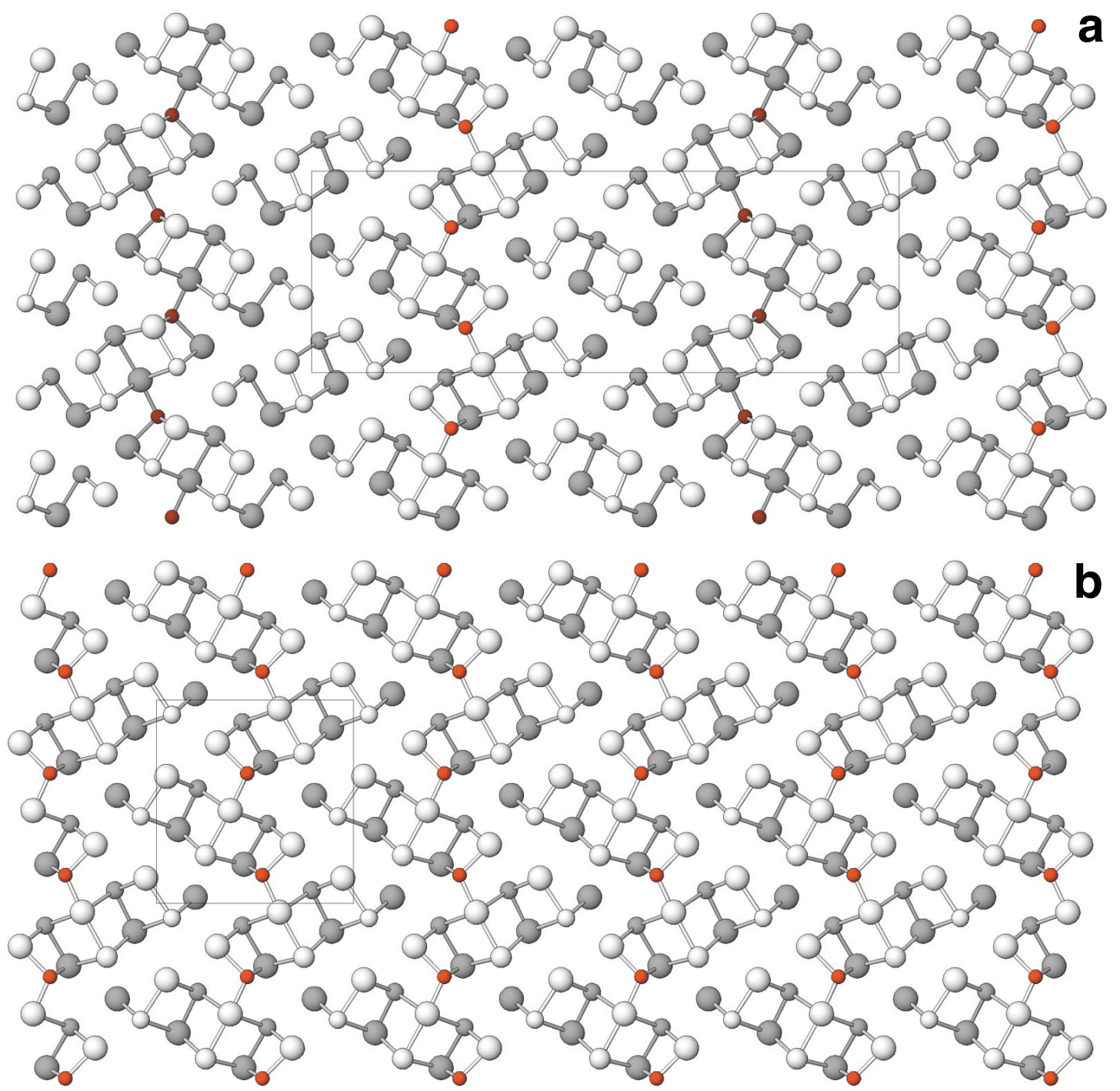

FIG. 3. (a) The crystal structure of stoichiometric gladite, with $33 \%$ of the aikinite end-member. (b) The crystal structure of stoichiometric krupkaite $\left(n_{\text {aik }}=50\right)$. In the order of increasing size, circles represent $\mathrm{Cu}$ (fully occupied positions, in red), bismuth, lead and sulfur. Shaded and void circles indicate two levels in $x$, approximately $2 \AA$ apart. Projections along [100], $b$ axis horizontal, $c$ vertical. 

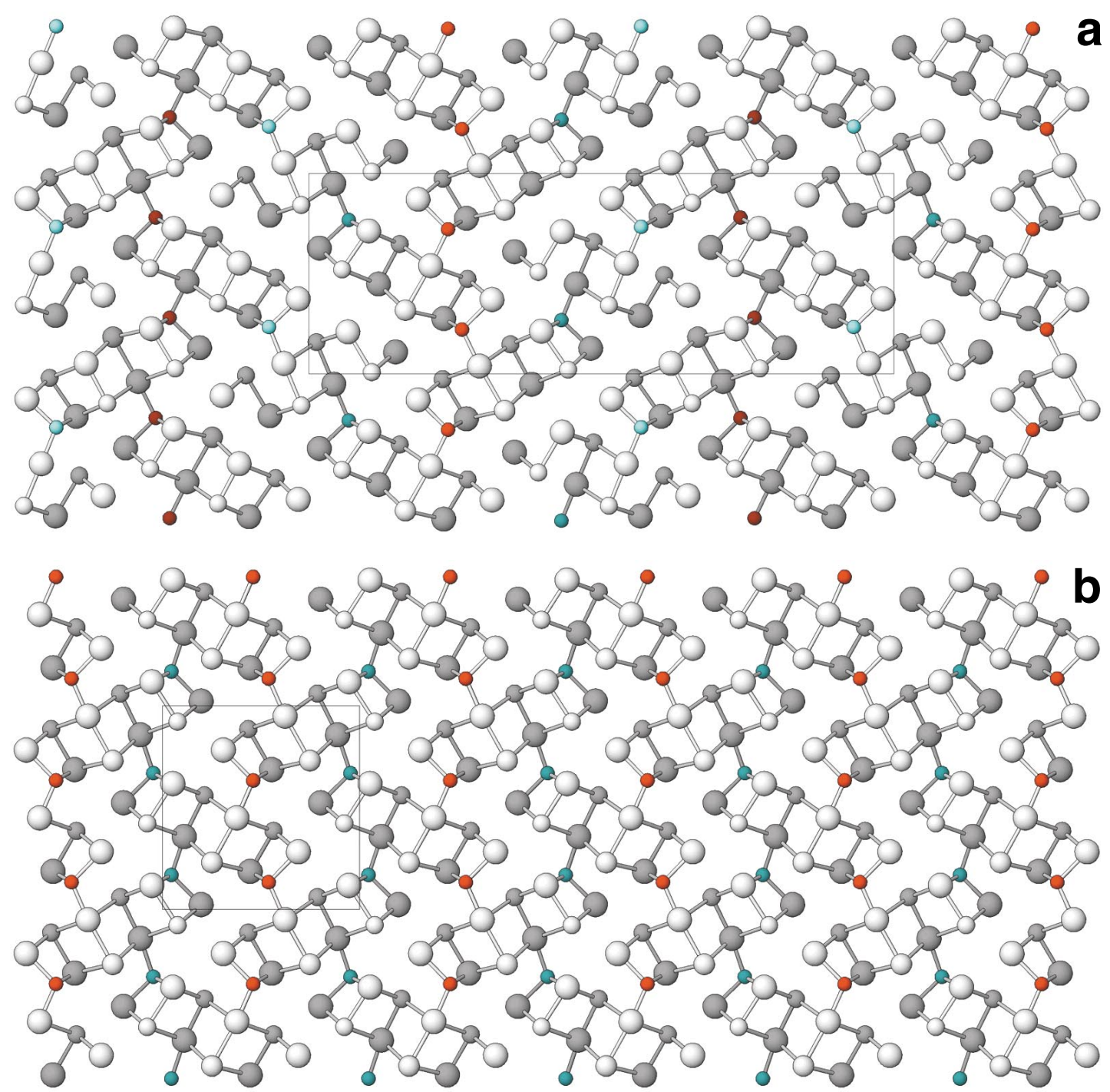

FIG. 4. (a) The crystal structure of oversubstituted gladite $\left(n_{\text {aik }}=39\right)$. (b) The crystal structure of oversubstituted krupkaite $\left(n_{\text {aik }}\right.$ $=59)$. The fully occupied $\mathrm{Cu}$ positions are indicated in red, the partly occupied ones ( $22 \%$ in gladite, $12 \%$ in krupkaite) in blue.

There is a significant general increase in the volumes $V_{\mathrm{P}}$ of the Bi polyhedra and those of their circumscribed spheres $\left(V_{\mathrm{s}}\right)$ with the increase in the overall $\mathrm{Cu}$-and- $\mathrm{Pb}$ for-vacancy-and-Bi substitution, from bismuthinite (Bi $1: V_{\mathrm{P}}$ and $V_{\mathrm{s}}$ respectively equal to $36.33 \AA^{3}$ and 106.93 $\AA^{3}$, Bi 2: $36.10 / 109.10 \AA^{3}$ ) toward the structures studied. A similar increase can also be observed in comparing the present $\mathrm{Pb}$ sites with the position of lead in aikinite $\left(V_{\mathrm{P}} / V_{\mathrm{s}}=40.15 \AA^{3} / 120.84 \AA^{3}\right)$. There are no sys- tematic differences between the two structures investigated, gladite and krupkaite, in comparisons of the corresponding terminal $\mathrm{Bi}$ positions, except for the observable influence of the adjacent $\mathrm{Pb}$ (Tables 5, 6). The differences between these two structures are concentrated in the central Bi positions.

In gladite, the $\mathrm{Bi} 1$ and $\mathrm{Bi} 2$ sites are in the "bismuthinite-like" ribbon. Their distortion characteristics are similar to those of $\mathrm{Bi}$ sites in $\mathrm{Bi}_{2} \mathrm{~S}_{3}$, but the 
TABLE 3. POSITIONAL AND DISPLACEMENT PARAMETERS FOR THE GLADITE AND KRUPKAITE STRUCTURES REFINED

\begin{tabular}{|c|c|c|c|c|c|c|c|c|}
\hline Atom occ. & $x$ & $y$ & $z$ & $\mathrm{U}_{\text {eq }}$ & $\mathrm{U}_{11}$ & $\mathrm{U}_{22}$ & $\mathrm{U}_{33}$ & $\mathbf{U}_{23}$ \\
\hline \multicolumn{9}{|c|}{ Gladite $\left(n_{\text {aik }}=33\right)$} \\
\hline $\mathrm{Bil}$ & 0.25 & $0.39201(2)$ & $0.50696(7)$ & $0.0421(2)$ & $0.0388(4)$ & $0.0442(4)$ & $0.0432(4)$ & $0.0040(3)$ \\
\hline $\mathrm{Bi2}$ & 0.75 & $0.48687(2)$ & $0.65683(7)$ & $0.0434(2)$ & $0.0434(4)$ & $0.0456(5)$ & $0.0412(4)$ & $-0.0007(3)$ \\
\hline $\mathrm{Bi3}$ & 0.25 & $0.05623(2)$ & $0.52112(7)$ & $0.0415(2)$ & $0.0388(4)$ & $0.0412(4)$ & $0.0444(4)$ & $0.0030(3)$ \\
\hline $\mathrm{Bi4}$ & 0.75 & $0.27078(2)$ & $0.47365(7)$ & $0.0424(2)$ & $0.0399(4)$ & $0.0470(5)$ & $0.0404(4)$ & $0.0021(3)$ \\
\hline $\mathrm{Bi} 5$ & 0.75 & $0.15429(2)$ & $0.64885(7)$ & $0.0439(2)$ & $0.0438(4)$ & $0.0447(5)$ & $0.0432(4)$ & $-0.0031(3)$ \\
\hline $\mathrm{Pb}$ & 0.25 & $0.16511(3)$ & $0.31833(7)$ & $0.0485(3)$ & $0.0477(5)$ & $0.0512(5)$ & $0.0468(5)$ & $0.0049(3)$ \\
\hline $\mathrm{Cu}$ & 0.25 & $0.23783(8)$ & $0.7205(2)$ & $0.0490(6)$ & $0.048(1)$ & $0.055(1)$ & $0.043(1)$ & $-0.002(1)$ \\
\hline $\mathrm{S} 1$ & 0.75 & $0.3516(1)$ & $0.6086(4)$ & $0.040(1)$ & $0.043(2)$ & $0.038(2)$ & $0.039(2)$ & $0.004(2)$ \\
\hline $\mathrm{S} 2$ & 0.75 & $0.4581(1)$ & $0.4482(4)$ & $0.039(1)$ & $0.039(2)$ & $0.039(2)$ & $0.039(2)$ & $0.000(2)$ \\
\hline S3 & 0.25 & $0.4333(1)$ & $0.7088(4)$ & $0.037(1)$ & $0.037(2)$ & $0.035(2)$ & $0.039(2)$ & $-0.001(2)$ \\
\hline $\mathrm{S} 4$ & 0.75 & $0.0178(1)$ & $0.6279(4)$ & $0.041(1)$ & $0.040(2)$ & $0.040(2)$ & $0.042(3)$ & $0.002(2)$ \\
\hline S5 & 0.75 & $0.1190(1)$ & $0.4484(4)$ & $0.039(1)$ & $0.038(2)$ & $0.038(2)$ & $0.040(2)$ & $0.002(2)$ \\
\hline S6 & 0.75 & $0.2306(1)$ & $0.2743(4)$ & $0.039(1)$ & $0.039(2)$ & $0.038(2)$ & $0.038(2)$ & $0.000(2)$ \\
\hline S7 & 0.25 & $0.3132(1)$ & $0.3714(4)$ & $0.040(1)$ & $0.043(2)$ & $0.037(2)$ & $0.041(2)$ & $-0.001(2)$ \\
\hline S8 & 0.25 & $0.2081(1)$ & $0.5379(4)$ & $0.040(1)$ & $0.041(2)$ & $0.044(2)$ & $0.037(2)$ & $0.000(2)$ \\
\hline 59 & 0.25 & $0.1023(1)$ & $0.7130(4)$ & $0.037(1)$ & $0.037(2)$ & $0.037(2)$ & $0,039(2)$ & $-0.001(2)$ \\
\hline \multicolumn{9}{|c|}{ Gladite $\left(n_{\text {ijk }}=39\right)$} \\
\hline Bil & 0.25 & $0.39243(3)$ & $08(7)$ & & $0.0339(5)$ & $0.0374(5)$ & $0.0377(5)$ & $0.0044(3)$ \\
\hline $\mathrm{Bi} 2$ & 0.75 & $0.48697(3)$ & $0.65794(8)$ & $0.0407(3)$ & $0.0379(5)$ & $0.0429(5)$ & $0.0414(5)$ & $0.0032(4)$ \\
\hline $\mathrm{Bi3}$ & 0.25 & $0.05679(2)$ & $0.52041(7)$ & $0.0358(3)$ & $0.0338(5)$ & $0.0343(5)$ & $0.0392(5)$ & $0.0022(3)$ \\
\hline $\mathrm{Bi} 4$ & 0.75 & $0.27130(3)$ & $0.47335(7)$ & $0.0360(3)$ & $0.0343(5)$ & $0.0394(5)$ & $0.0343(5)$ & $0.0020(3)$ \\
\hline Bi5 & 0.75 & $0.15535(3)$ & $0.64725(8)$ & $0.0397(3)$ & $0.0406(5)$ & $0.0398(5)$ & $0.0386(5)$ & $-0.0035(3)$ \\
\hline $\mathrm{Pbl}$ & 0.25 & $0.16514(3)$ & $0.31690(8)$ & $0.0422(3)$ & $0.0431(5)$ & $0.0431(5)$ & $0.0405(5)$ & $0.0040(4)$ \\
\hline $\mathrm{Cu} 1$ & 0.25 & $0.23800(9)$ & $0.7207(2)$ & $0.0419(7)$ & $0.042(1)$ & $0.046(2)$ & $0.037(1)$ & $-0.004(1)$ \\
\hline $\mathrm{Cu} 2 \quad 0.223(7)$ & 0.75 & $0.4318(3)$ & $0.2672(8)$ & $0.042 *$ & & & & \\
\hline S1 & 0.75 & $0.3517(2)$ & $0.6088(5)$ & $0.033(1)$ & $0.036(3)$ & $0.032(3)$ & $0.032(2)$ & $0.001(2)$ \\
\hline $\mathrm{S} 2$ & 0.75 & $0.4574(2)$ & $0.4484(5)$ & $0.033(1)$ & $0.035(2)$ & $0.031(3)$ & $0.033(2)$ & $0.000(2)$ \\
\hline$\$ 3$ & 0.25 & $0.4332(2)$ & $0.7091(4)$ & $0.031(1)$ & $0.034(3)$ & $0.027(2)$ & $0.032(2)$ & $0.001(2)$ \\
\hline S4 & 0.75 & $0.0180(2)$ & $0.6268(4)$ & $0.033(1)$ & $0.035(3)$ & $0.032(3)$ & $0.032(3)$ & $0.001(2)$ \\
\hline S5 & 0.75 & $0.1192(2)$ & $0.4480(5)$ & $0.032(1)$ & $0.035(3)$ & $0.029(3)$ & $0.032(2)$ & $0.001(2)$ \\
\hline S6 & 0.75 & $0.2307(2)$ & $0.2753(5)$ & $0.032(1)$ & $0.033(2)$ & $0.028(2)$ & $0.034(3)$ & $0.000(2)$ \\
\hline S7 & 0.25 & $0.3132(2)$ & $0.3702(4)$ & $0.034(1)$ & $0.038(3)$ & $0.031(3)$ & $0.032(2)$ & $0.000(2)$ \\
\hline S8 & 0.25 & $0.2082(2)$ & $0.5385(5)$ & $0.035(1)$ & $0.038(3)$ & $0.036(3)$ & $0.031(2)$ & $0.000(2)$ \\
\hline 59 & 0.25 & $0.1023(2)$ & $0.7126(4)$ & $0.031(1)$ & $0.035(2)$ & $0.027(2)$ & $0.032(3)$ & $-0.001(2)$ \\
\hline
\end{tabular}

volumes are distinctly larger. Analysis of bond lengths shows that the short and intermediate $\mathrm{Bi}-\mathrm{S}$ distances are broadly similar, whereas the longest $\mathrm{Bi}-\mathrm{S}$ distances in the bismuthinite-like ribbon of gladite are longer than the corresponding distances in bismuthinite: $3.07 \AA$ versus $3.04 \AA$ for $\mathrm{Bi} 1$ and $2 \times 3.345 \AA$ versus $2 \times 3.323$ $\AA$ for Bi 2. The increase in unit-cell parameters thus takes place primarily in the inter-ribbon spaces.

The terminal bismuth sites ( $\mathrm{Bi} 4$ in gladite and $\mathrm{Bi} 2$ in krupkaite) that are attached to the central $\mathrm{Pb} 1$ polyhedron have sphere and polyhedron volumes slightly larger than those attached to central Bi (Tables 5, 6). The central $\mathrm{Bi}$ atoms ( $\mathrm{Bi} 5$ in gladite and $\mathrm{Bi} 3$ in krupkaite) in the "krupkaite-like" ribbons have larger volumes, eccentricities and volume distortions and lower sphericities than those in "bismuthinite-like" ribbons of gladite ( $\mathrm{Bi} 2$ in Table 5) or $\mathrm{Bi}_{2} \mathrm{~S}_{3}$ (Table 6). These differences seem to be caused by a "sandwiching" between the large $\mathrm{Pb} 1$ polyhedron on the one side and the $\mathrm{Cu} 1$ tetrahedron on the other (Figs. 3a, b). A comparison of interatomic distances ( $\mathrm{Bi} 2$ in gladite: $2.582,2 \times 2.757,2 \times 2.979$ and $2 \times 3.345 \AA$ versus $\mathrm{Bi}$ 5 in gladite: $2.588,2 \times 2.756,2 \times 2.983$ and $2 \times 3.424$ $\AA$ ) shows that the elongation of the lone-electron-paircontaining prismatic part of the $\mathrm{Bi}$ coordination polyhedron bears the bulk of these adjustments.

All the characteristics of the $\mathrm{Pb} 1$ positions for krupkaite $\left(n_{\text {aik }}=47\right)$ and krupkaite $\left(n_{\text {aik }}=50\right)$ are virtually identical, although all the deviations in the $\mathrm{Pb}_{94} \mathrm{Bi}_{6}$ position in the former point in the right direction (e.g., the polyhedron has a smaller volume and higher averaged eccentricity than the pure $\mathrm{Pb}$ position, Table 6). In krupkaite $\left(n_{\text {aik }}=59\right)$, the polyhedron and circumscribedsphere volumes for this position noticeably increase, together with those of the other polyhedra ( $\mathrm{Bi} 1$ and $\mathrm{Cu}$ 1) that are influenced indirectly by cation exchange (Table 6). This increase is in agreement with the observed increase in the unit-cell volume, reflecting 
TABLE 3 (cont'd). POSITIONAL AND DISPLACEMENT PARAMETERS FOR THE GLADITE AND KRUPKAITE STRUCTURES REFINED

\begin{tabular}{|c|c|c|c|c|c|c|c|c|c|}
\hline Atom & occ & $x$ & $y$ & $z$ & $\mathrm{U}_{\text {ox }}$ & $\mathrm{U}_{11}$ & $\mathrm{U}_{22}$ & $\mathrm{U}_{33}$ & $\mathbf{U}_{23}$ \\
\hline \multicolumn{10}{|c|}{ Krupkaite $\left(n_{\text {aik }}=47\right)$} \\
\hline Bi1 & & 0 & $0.92144(8)$ & $0.42290(7)$ & $0.0334(2)$ & $0.0320(5)$ & $0.0323(4)$ & $0.0360(4)$ & $0.0042(3)$ \\
\hline $\mathrm{Bi} 2$ & & 0.5 & $0.56408(8)$ & $0.38615(8)$ & $0.0344(2)$ & $0.0341(5)$ & $0.0362(4)$ & $0.0330(4)$ & $0.0023(3)$ \\
\hline $\mathrm{Bi3}$ & & 0.5 & $0.21067(9)$ & $0.55937(7)$ & $0.0367(2)$ & $0.0380(5)$ & $0.0357(5)$ & $0.0365(4)$ & $-0.0032(3)$ \\
\hline $\mathrm{Pb} 1$ & & 0.0 & $0.2513(1)$ & $0.23076(9)$ & $0.0417(3)$ & $0.0420(6)$ & $0.0427(5)$ & $0.0405(4)$ & $0.0068(4)$ \\
\hline $\mathrm{Cu} 1$ & $0.98(1)$ & 0 & $0.4611(4)$ & $0.6332(3)$ & $0.042^{*}$ & & & & \\
\hline S1 & & 0.5 & $0.8029(5)$ & $0.5255(5)$ & $0.031(1)$ & $0.034(3)$ & $0.027(2)$ & $0.032(2)$ & $0.000(2)$ \\
\hline $\mathbf{S} 2$ & & 0.5 & $0.1106(6)$ & $0.3577(5)$ & $0.032(1)$ & $0.034(3)$ & $0.032(3)$ & $0.030(2)$ & $0.000(2)$ \\
\hline s3 & & 0.5 & $0.4446(5)$ & $0.1885(5)$ & $0.032(1)$ & $0.033(3)$ & $0.030(3)$ & $0.034(3)$ & $-0.002(2)$ \\
\hline S4 & & 0.0 & $0.6904(5)$ & $0.2822(5)$ & $0.033(1)$ & $0.042(3)$ & $0.025(2)$ & $0.032(2)$ & $-0.004(2)$ \\
\hline S5 & & 0.0 & $0.3758(5)$ & $0.4510(4)$ & $0.030(1)$ & $0.034(3)$ & $0.028(3)$ & $0.028(3)$ & $-0.002(2)$ \\
\hline \$6 & & 0.0 & $0.0531(5)$ & $0.6201(5)$ & $0.030(1)$ & $0.033(3)$ & $0.026(3)$ & $0.031(2)$ & $0.000(2)$ \\
\hline \multicolumn{10}{|c|}{ Krupkaite $\left(n_{\text {aik }}=50\right)$} \\
\hline $\mathrm{Bi} 1$ & & 0 & $0.92106(9)$ & 0.427 & 0.032 & 0.031 & 0.033 & $0.0328(6)$ & $-0.0038(4)$ \\
\hline $\mathrm{Bi} 2$ & & 0.5 & $0.56344(9)$ & $0.39079(9)$ & $0.0330(3)$ & $0.0315(5)$ & $0.0379(5)$ & $0.0295(5)$ & $-0.0015(4)$ \\
\hline $\mathrm{Bi3}$ & & 0.5 & $0.21048(9)$ & $0.56429(8)$ & $0.0352(3)$ & $0.0347(5)$ & $0.0377(5)$ & $0.0330(5)$ & $0.0038(4)$ \\
\hline $\mathrm{Pbl}$ & & 0.0 & $0.2507(1)$ & $0.2357(1)$ & $0.0381(3)$ & $0.0394(6)$ & $0.0399(5)$ & $0.0351(6)$ & $0.0033(4)$ \\
\hline $\mathrm{Cu} 1$ & & 0.0 & $0.4612(3)$ & $0.6386(3)$ & $0.0390(8)$ & $0.037(2)$ & $0.048(2)$ & $0.032(2)$ & $0.003(2)$ \\
\hline S1 & & 0.5 & $0.8021(6)$ & $0.5304(6)$ & $0.031(1)$ & $0.035(3)$ & $0.029(3)$ & $0.030(3)$ & $-0.005(2)$ \\
\hline S2 & & 0.5 & $0.1104(6)$ & $0.3629(6)$ & $0.030(1)$ & $0.030(3)$ & $0.033(3)$ & $0.027(3)$ & $-0.004(2)$ \\
\hline S3 & & 0.5 & $0.4447(6)$ & $0.1920(6)$ & $0.033(1)$ & $0.041(4)$ & $0.034(3)$ & $0.024(3)$ & $0.004(3)$ \\
\hline S4 & & 0.0 & $0.6901(5)$ & $0.2882(6)$ & $0.029(1)$ & $0.033(3)$ & $0.028(3)$ & $0.025(3)$ & $0.002(3)$ \\
\hline S5 & & 0.0 & $0.3751(6)$ & $0.4563(5)$ & $0.032(1)$ & $0.034(3)$ & $0.036(3)$ & $0.026(4)$ & $0.002(3)$ \\
\hline S6 & & 0.0 & $0.0531(6)$ & $0.6241(6)$ & $0.028(1)$ & $0.025(3)$ & $0.031(3)$ & $0.029(3)$ & $0.001(3)$ \\
\hline \multicolumn{10}{|c|}{ Krupkaite $\left(n_{\text {2ik }}=59\right)$} \\
\hline $\mathrm{Bil}$ & & 0 & $0.9232(1)$ & $0.4225(1)$ & 0.03 & $0.0320(6)$ & 0.03 & $0.0382(7)$ & 0.003 \\
\hline $\mathrm{Bi} 2$ & & 0.5 & $0.5641(1)$ & $0.3857(1)$ & $0.0359(4)$ & $0.0328(7)$ & $0.0389(7)$ & $0.0360(6)$ & $0.0007(5)$ \\
\hline Bi3* & & 0.5 & $0.2134(1)$ & $0.5602(1)$ & $0.0452(4)$ & $0.0384(7)$ & $0.0509(9)$ & $0.0462(7)$ & $0.0018(7)$ \\
\hline$\left[\mathrm{Bi}^{*}\right.$ & 0.82 & 0.5 & $0.2105(3)$ & $0.5585(2)$ & $0.0402(8)]$ & & & & \\
\hline $\mathrm{Pb}^{*}$ & 0.18 & 0.5 & $0.233(1)$ & $0.572(1)$ & $0.052(5)]$ & & & & \\
\hline $\mathrm{PbI}$ & & 0.0 & $0.2516(1)$ & $0.2307(1)$ & $0.0418(4)$ & $0.0404(8)$ & $0.0408(7)$ & $0.0441(7)$ & $0.0051(6)$ \\
\hline $\mathrm{Cu} 1$ & & 0.0 & $0.4606(5)$ & $0.6334(4)$ & $0.042(1)$ & $0.038(2)$ & $0.050(3)$ & $0.038(2)$ & $0.000(2)$ \\
\hline $\mathrm{Cu} 2$ & $0.12(1)$ & 0.5 & $0.046(4)$ & $0.169(4)$ & $0.042^{* *}$ & & & & \\
\hline S1 & & 0.5 & $0.8033(8)$ & $0.5235(8)$ & $0.033(2)$ & $0.038(4)$ & $0.026(4)$ & $0.035(3)$ & $0.004(3)$ \\
\hline $\mathrm{S} 2$ & & 0.5 & $0.1113(8)$ & $0.3578(7)$ & $0.034(2)$ & $0.034(4)$ & $0.032(4)$ & $0.036(4)$ & $0.002(3)$ \\
\hline S3 & & 0.5 & $0.4456(7)$ & $0.1867(7)$ & $0.031(2)$ & $0.029(4)$ & $0.027(4)$ & $0.035(4)$ & $0.001(3)$ \\
\hline S4 & & 0.0 & $0.6902(8)$ & $0.2828(8)$ & $0.034(2)$ & $0.032(4)$ & $0.030(4)$ & $0.039(4)$ & $0.001(4)$ \\
\hline S5 & & 0.0 & $0.3774(8)$ & $0.4493(7)$ & $0.037(2)$ & $0.035(4)$ & $0.036(5)$ & $0.040(5)$ & $-0.006(4)$ \\
\hline S6 & & 0.0 & $0.0532(8)$ & $0.6178(8)$ & $0.033(2)$ & $0.031(4)$ & $0.034(4)$ & $0.034(4)$ & $-0.001(3)$ \\
\hline
\end{tabular}

Note: The percentage of the aikinite end-member in the member of the bismuthinite-aikinite solid-solution series is indicated by $n_{\text {aik. }}$. Full site occupancies where not indicated otherwise. ${ }^{*}$ Oversubstituted krupkaite was also refined with the $\mathrm{Bi} 3$ position split into $0.82 \mathrm{Bi} 3$ and $0.18 \mathrm{~Pb} 2$, respectively, giving the positional parameters and isotropic displacement factors indicated in square brackets. ** Fixed, equal to that of Cul.

"oversubstitution". Both measures of volume for the terminal Bi 2 polyhedron remain constant in this exchange. In gladite, the presence of the partly occupied $\mathrm{Cu} 2$ position seems to provoke more pronounced changes in the bond lengths and polyhedron volume (Table 5) of the Bi 2 position of the adjacent bismuthinite-like chain $[2.607,2 \times 2.762,2 \times 3.002$ and $2 \times$ $3.352 \AA$ ] (to be compared with the values for gladite, $n_{\text {aik }}=33$, as given above) than in the corresponding characteristics of the Bi 5 position in the krupkaite-like chains, to which $\mathrm{Cu} 2$ is attached $(2.593,2 \times 2.786,2$ $\times 2.956$ and $2 \times 3.423 \AA$, versus the values given above). This observation opens up a possibility of accommodating additional $\mathrm{Pb}$ in the central positions of the bismuthinite-like ribbons instead of in such portions of the krupkaite-like ribbons adjacent to $\mathrm{Cu} 2$. This alternative deserves further investigation by appropriate diffraction methods.

The mixed "Bi3" position in krupkaite $\left(n_{\text {aik }}=59\right)$ shows clearly an augmented volume of polyhedron and 
TABLE 5. POLYHEDRON CHARACTERISTICS FOR THE GLADITE STRUCTURES REFINED AND BISMUTHINITE

\begin{tabular}{|c|c|c|c|c|c|c|c|}
\hline Atom & $\mathrm{CN}$ & $\begin{array}{l}\text { Sphere } \\
\text { radius }\end{array}$ & $\begin{array}{l}\text { Sphere } \\
\text { volume }\end{array}$ & $\begin{array}{l}\text { Polyhedron } \\
\text { volume }\end{array}$ & $\begin{array}{c}\text { Volume } \\
\text { distortion }\end{array}$ & $\begin{array}{l}\text { Eccen- } \\
\text { tricity }^{(2)}\end{array}$ & $\begin{array}{l}\text { Spher- } \\
\text { icity }^{(3)}\end{array}$ \\
\hline $\mathrm{Bil}_{33}$ & 7 & 2.954 & 108.01 & 36.83 & 0.0989 & 0.3632 & 0.9677 \\
\hline $\mathrm{Bil}_{39}$ & 7 & 2.954 & 108.01 & 36.81 & 0.0995 & 0.3696 & 0.9604 \\
\hline $\mathrm{Bi}_{33}$ & 7 & 2.974 & 110.19 & 36.48 & 0.1252 & 0.4163 & 0.9611 \\
\hline $\mathrm{Bi}_{39}$ & 7 & 2.987 & 111.67 & 37.02 & 0.124 & 0.4111 & 0.9593 \\
\hline $\mathrm{Bi}_{33}$ & 7 & 2.956 & 108.23 & 36.6 & 0.1063 & 0.4199 & 0.8963 \\
\hline $\mathrm{Bi}_{39}$ & 7 & 2.958 & 108.37 & 36.67 & 0.1059 & 0.4166 & 0.8988 \\
\hline $\mathrm{Bi4}_{33}$ & 7 & 2.957 & 108.32 & 37 & 0.097 & 0.377 & 0.9504 \\
\hline $\mathrm{Bi}_{39}$ & 7 & 2.963 & 109.02 & 37.18 & 0.0986 & 0.3847 & 0.9503 \\
\hline $\mathrm{BiS}_{33}$ & 7 & 3 & 113.05 & 37.25 & 0.1292 & 0.4483 & 0.9374 \\
\hline $\mathrm{BiS}_{39}$ & 7 & 3 & 113.07 & 37.29 & 0.1285 & 0.4367 & 0.9379 \\
\hline $\mathrm{Pbl}_{33}$ & 7 & 3.031 & 116.69 & 38.42 & 0.1299 & 0.1642 & 0.977 \\
\hline $\mathrm{Pbl}_{39}$ & 7 & 3.035 & 117.05 & 38.55 & 0.1297 & 0.1489 & 0.9735 \\
\hline $\mathrm{Cu}_{33}$ & 4 & 2.357 & 54.82 & 6.56 & 0.0239 & 0.0988 & 1 \\
\hline $\mathrm{Cu}_{39}$ & 4 & 2.356 & 54.79 & 6.54 & 0.0256 & 0.0929 & 1 \\
\hline $\mathrm{Cu}_{39}$ & 4 & 2.343 & 53.86 & 6.45 & 0.022 & 0.1195 & 1 \\
\hline $\mathrm{Bi} 1$ & 7 & 2.944 & 106.93 & 36.33 & 0.1022 & 0.3749 & 0.9625 \\
\hline $\mathrm{Bi} 2$ & 7 & 2.964 & 109.1 & 36.1 & 0.1255 & 0.409 & 0.9573 \\
\hline$\square$ tet & 4 & 2.319 & 52.23 & 6.26 & 0.0219 & - & 1 \\
\hline
\end{tabular}

Subscripts indicate the phases involved: gladite $\left(\mathrm{n}_{\mathrm{aik}}=33\right)$ and oversubstituted gladite $\left(\mathrm{n}_{\text {aik }}=39\right)$. Bi 1 and Bi 2 are, respectively, the terminal and the central Bi positions in a ribbon of a newly refined structure of synthetic bismuthinite (in prep.). and $\square$ tet is the empty tetrahedral position in this structure. Sphere radius is expressed in $\AA$, whereas sphere volume and polyhedron volume are expressed in $\AA^{3}$. The centroid parameters (1) to (3) are explained in a footnote to Table 6.

sphere in this "oversubstituted" structure (Table 6), whereas other characteristics for the mixed polyhedron do not differ substantially from those of a pure Bi site (only the eccentricity drops marginally). After splitting, the independent Bi 3 site (occupancy 0.82) is highly eccentric, whereas the associated $\mathrm{Pb} 2$ site has a significantly decreased eccentricity (Table 3 ). We were not able to model similar splitting for the mixed Bi site(s) in gladite $\left(n_{\text {aik }}=39\right)$.

A comparison of $M e-S$ distances (Table 4, deposited) shows virtually no change between the $\mathrm{Pb} 1$ position in krupkaite $\left(n_{\text {aik }}=59\right)$ and that in krupkaite $\left(n_{\text {aik }}=\right.$ 50): $2.900(10), 2 \times 2.947(7), 2 \times 3.012(7)$ and $2 \times$ $3.189(7) \AA$ in the former against $2.906(6), 2 \times 2.943(5)$, $2 \times 3.001(5)$ and $2 \times 3.164(5) \AA$ in the latter. The partly occupied $\mathrm{Pb} 2$ position in $n_{\text {aik }}=59$, associated with the Bi 3 position, has significantly shorter $\mathrm{Me}-\mathrm{S}$ distances: $2.84(1), 2 \times 2.90(1), 2 \times 2.95(1)$ and a longer pair $2 \times$ $3.28(2)$; this is caused by the averaged character of the surrounding sulfur positions. The asymmetry of interatomic distances for the Bi 3 position is augmented, apparently due to the enlargement of the (average) coordination polyhedron by insertion of substitutional $\mathrm{Pb}$.

The fully occupied $\mathrm{Cu} 1$ sites in krupkaite have a slightly eccentric tetrahedral coordination typical of the bismuthinite-aikinite derivatives. Their eccentricity (Table 6) is comparable with that for $\mathrm{Cu} 1$ in aikinite
(0.080, our data) and slightly lower than the values for fully occupied $\mathrm{Cu}$ sites in salzburgite, $\mathrm{Cu}_{1.6} \mathrm{~Pb}_{1.6} \mathrm{Bi}_{6.4} \mathrm{~S}_{12}$ (Topa et al. 2000) and in both gladite samples studied (Table 5). The polyhedron characteristics for the partly occupied Cu 2 sites (Figs. 4a, b, Tables 5, 6) resemble closely those of the full tetrahedrally coordinated sites. The differences observed can be ascribed to the results of averaging of S positions over the empty and filled tetrahedra around the partly occupied copper sites.

\section{Modular aspects}

Pring (1989) studied two variants of oversubstituted krupkaite, $\mathrm{Cu}_{1.03} \mathrm{~Pb}_{1.03} \mathrm{Bi}_{2.97} \mathrm{~S}_{6}$ and $\mathrm{Cu}_{1.1} \mathrm{~Pb}_{1.1} \mathrm{Bi}_{2.9} \mathrm{~S}_{6}$, as well as one sample of "ideal" krupkaite, $\mathrm{CuPbBi}_{3} \mathrm{~S}_{6}$, by means of electron diffraction and HRTEM. He indicated the presence of faint disorder-induced streaks parallel

\section{TABLE 6. POLYHEDRON CHARACTERISTICS FOR THE} KRUPKAITE STRUCTURES REFINED

\begin{tabular}{|c|c|c|c|c|c|c|c|}
\hline Atom & $\mathrm{CN}$ & $\begin{array}{l}\text { Sphere } \\
\text { radius }\end{array}$ & $\begin{array}{l}\text { Sphere } \\
\text { volume }\end{array}$ & $\begin{array}{l}\text { Polyhedron } \\
\text { volume }\end{array}$ & $\begin{array}{c}\text { Volume } \\
\text { distortion }^{(1)}\end{array}$ & $\begin{array}{l}\text { Eccen- } \\
\text { tricity }^{(2)}\end{array}$ & $\begin{array}{l}\text { Spher- } \\
\text { icity }^{(3)}\end{array}$ \\
\hline $\mathrm{Bil}_{47}$ & 7 & 2.955 & 108.13 & 36.75 & 0.102 & 0.3907 & 0.9213 \\
\hline $\mathrm{Bil}_{50}$ & 7 & 2.956 & 108.2 & 36.78 & 0.1017 & 0.3937 & 0.9201 \\
\hline $\mathrm{Bil}_{5 \varkappa \mathrm{u}}$ & 7 & 2.96 & 108.67 & 36.94 & 0.1018 & 0.4046 & 0.9213 \\
\hline $\mathrm{Bil}_{5 \%}$ & 7 & 2.96 & 108.68 & 36.93 & 0.102 & 0.4055 & 0.9208 \\
\hline $\mathrm{Bi}_{47}$ & 7 & 2.969 & 109.61 & 37.32 & 0.1004 & 0.3875 & 0.9451 \\
\hline $\mathrm{Bi}_{30}$ & 7 & 2.966 & 109.28 & 37.26 & 0.0989 & 0.3835 & 0.9464 \\
\hline $\mathrm{Bi} 2_{59 u}$ & 7 & 2.967 & 109.36 & 37.26 & 0.0996 & 0.3816 & 0.9418 \\
\hline $\mathrm{Bi} 2_{393}$ & 7 & 2.967 & 109.41 & 37.27 & 0.0997 & 0.3811 & 0.9426 \\
\hline $\mathrm{Bi}_{47}$ & 7 & 3.014 & 114.68 & 37.87 & 0.1273 & 0.4556 & 0.941 \\
\hline $\mathrm{Bi}_{50}$ & 7 & 3.015 & 114.78 & 37.85 & 0.1286 & 0.4613 & 0.9377 \\
\hline $\mathrm{Bi} 3_{59 \mathrm{u}}$ & 7 & 3.026 & 116.11 & 38.29 & 0.1285 & 0.4423 & 0.9449 \\
\hline $\mathrm{Bi} 3_{59 \mathrm{x}}$ & 7 & 3.026 & 116.07 & 38.28 & 0.1285 & 0.4666 & 0.9439 \\
\hline $\mathrm{Pbl}_{47}$ & 7 & 3.023 & 115.69 & 38.22 & 0.1269 & 0.1562 & 0.975 \\
\hline $\mathrm{Pbl}_{50}$ & 7 & 3.024 & 115.81 & 38.26 & 0.127 & 0.1536 & 0.9766 \\
\hline $\mathrm{Pbl}_{\text {squ }}$ & 7 & 3.035 & 117.11 & 38.68 & 0.1272 & 0.1696 & 0.9761 \\
\hline $\mathrm{Pbl}_{59 \mathrm{~m}}$ & 7 & 3.035 & 117.1 & 38.71 & 0.1265 & 0.1691 & 0.9767 \\
\hline $\mathrm{Pb} 2_{593}$ & & 3.026 & 116.07 & 38.28 & 0.1285 & 0.2581 & 0.9439 \\
\hline $\mathrm{Cul}_{47}$ & & 2.355 & 54.71 & 6.52 & 0.0276 & 0.0827 & 1 \\
\hline $\mathrm{Cul}_{50}$ & & 2.354 & 54.61 & 6.51 & 0.0264 & 0.0853 & 1 \\
\hline $\mathrm{Cu}_{39,12}$ & & 2.358 & 54.92 & 6.55 & 0.0272 & 0.0788 & 1 \\
\hline $\mathrm{Cu}_{59,}$ & & 2.357 & 54.82 & 6.54 & 0.027 & 0.0839 & 1 \\
\hline $\mathrm{Cu} 2_{s 9 u}$ & & 2.358 & 54.91 & 6.58 & 0.0217 & 0.0651 & 1 \\
\hline $\mathrm{Cu} 2_{599}$ & & 2.357 & 54.84 & 6.57 & 0.0219 & 0.0824 & 1 \\
\hline
\end{tabular}

Notes: Subscripts indicate the phases involved: undersubstituted krupkaite $\left(\mathrm{n}_{\text {aik }}=47\right)$, stoichiometric krupkaite $\left(\mathrm{n}_{\text {aik }}=50\right)$, and oversubstituted krupkaite $\left(\mathrm{n}_{\text {aik }}=59\right)$. The centroid parameters used defined in Balić-Zunić \& Makovicky (1996) and Makovicky \& Balić-Zunić (1998). The volume distortions are calculated using the maximum-volume polyhedron for respective $\mathrm{CN}$ ( 7 for a regular pentagonal bipyramid, 4 for a regular tetrahedron) as ideal reference. Sphere radius is expressed in $\AA$, whereas sphere volume and polyhedron volume are expressed in $\AA^{3}$.

(1) Volume distortion $v=[\mathrm{V}($ ideal $)-\mathrm{V}$ (polyhedron $] / \mathrm{V}$ (ideal) to be multiplied by 100 to obtain percentage.

(2) "Volume-based" eccentricity $\mathrm{ECC}_{\mathrm{v}}=1-\left[\left(\mathrm{r}_{\mathrm{s}}-\Delta\right) / \mathrm{r}_{\mathrm{s}}\right]^{3}$, where $\mathrm{r}_{\mathrm{s}}$ is the radius of the circumscribed sphere, and $\Delta$ is the distance between the sphere's center ("centroid") and the central atom.

(3) "Volume-based" sphericity $\mathrm{SPH}_{\mathrm{v}}=1-3 \sigma_{\mathrm{r}} \mathrm{r}_{\mathrm{s}}$, where $\sigma_{\mathrm{r}}$ is a standard deviation of the radius $r_{\mathrm{s}}$.

Values indicated by a "u" are valid for a refinement with an unsplit (Bi.Pb)3 position; those indicated by "s" describe a refinement with a pair of sites, Bi 3 and $\mathrm{Pb} 2$. 
to $[010]^{*}$ (our notation) in the diffraction images of oversubstituted krupkaite and an intergrowth of aikinite "units" in a krupkaite matrix in the corresponding HRTEM images. This does not contradict our results on krupkaite $\left(n_{\text {aik }}=59\right)$, which also shows faint streaks parallel to $[010]^{*}$, interconnecting and surrounding some strong, sharp reflections. Our data suggest that for the crystal from the Felbertal deposit, the formation of randomly scattered strips of aikinite, which presumably are of only finite length (see Pring 1995), proceeds via conversion of some of those (010) planes in krupkaite, which contain $\mathrm{Bi}+$ tetrahedral vacancies, into occasional (fragments of ) planes containing $\mathrm{Pb}+\mathrm{Cu}$. It does not proceed via insertion of aikinite strips that are one ribbon or an odd number of ribbons thick: such strips would offset the following portion of krupkaite structure by $1 / 2 b$ and create anti-phase domains, which ought to show up in the structure refinement as partial occupancies of the $\mathrm{Cu} 1$ and $\mathrm{Cu} 2$ sites in different proportions. This phenomenon might account for the 80:20 occupancy ratio for the two $\mathrm{Cu}$ sites in the structure refinement of krupkaite by Mumme (1975). It should be noted that during the structure refinement, krupkaite $\left(n_{\text {aik }}=59\right)$ was treated as an untwinned crystal, and the Flack parameter, indicated by the SHELXTL program, fluctuated between zero and 0.1 , with a standard deviation of 0.03 . The pattern of distribution for excess $\mathrm{Cu}$ in the structure of oversubstituted gladite, found in this study, precludes its explanation by insertion of krupkaite-like strips in the structure of gladite.

\section{ACKNOWLEDGEMENTS}

This project was supported by the research grants of the Danish Natural Science Research Council and by a grant to D. Topa from the University of Salzburg, Austria. The professional help of Miss Helene Almind and Mrs. Camilla Sarantaris as well as the helpful suggestions of D.J.M. Bevan, A. Pring and R.F. Martin are gratefully acknowledged.

\section{REFERENCES}

Balić-Žunić, T. \& MAKovicky, E. (1996): Determination of the centroid or "the best centre" of a coordination polyhedron. Acta Crystallogr. B52, 78-81.

Topa, D. \& Makovicky, E. (2002): The crystal structure of emilite, $\mathrm{Cu}_{10.7} \mathrm{~Pb}_{10.7} \mathrm{Bi}_{21.3} \mathrm{~S}_{48}$, the second $45 \AA$ derivative of the bismuthinite-aikinite solid-solution series. Can. Mineral. 40, 239-245.

Borodayev, Y.S., Mozgova, N.N. \& Vyalsov, L.N. (1970): The isomorphous series bismuthinite-aikinite. Vestnik Mosk. Univ. 1970(1), 18-33 (in Russ.).

Chen, T.T., Kirchner, E. \& PAAR, W. (1978): Friedrichite, $\mathrm{Cu}_{5} \mathrm{~Pb}_{5} \mathrm{Bi}_{7} \mathrm{~S}_{18}$, a new member of the aikinite-bismuthinite series. Can. Mineral. 16, 127-130.
Ciobanu, C. \& CoоK, N.J. (2000): Intergrowths of bismuth sulphosalts from the Ocna de Fier Fe-skarn deposit, Banat, southwest Romania. Eur. J. Mineral. 12, 899-917.

HARRIS, D.C. \& CHEN, T.T. (1976): Crystal chemistry and reexamination of nomenclature of sulfosalts in the aikinitebismuthinite series. Can. Mineral. 14, 194-205.

HoRIUCHI, H. \& WuENSCH, B.J. (1976): The ordering scheme for metal atoms in the crystal structure of hammarite, $\mathrm{Cu}_{2} \mathrm{~Pb}_{2} \mathrm{Bi}_{4} \mathrm{~S}_{9}$. Can. Mineral. 14, 536-539.

$\&$ (1977): Lindströmite, $\mathrm{Cu}_{3} \mathrm{~Pb}_{3} \mathrm{Bi}_{7} \mathrm{~S}_{15}$ : its space group and ordering scheme for metal atoms in the crystal structure. Can. Mineral. 15, 527-535.

KoHATsu, I. \& WUENSCH, B.J. (1971): The crystal structure of aikinite, $\mathrm{PbCuBiS}_{3}$. Acta Crystallogr. B27, 1245-1252.

\& (1976): The crystal structure of gladite, $\mathrm{PbCuBi}_{5} \mathrm{~S}_{9}$, a superstructure intermediate in the series $\mathrm{Bi}_{2} \mathrm{~S}_{3}-\mathrm{PbCuBiS}_{3}$ (bismuthinite-aikinite). Acta Crystallogr. B32, 2401-2409.

KuPČíK, V. \& VesElÁ-NovÁKovÁ, L. (1970): Zur Kristallstruktur des Bismuthinits, $\mathrm{Bi}_{2} \mathrm{~S}_{3}$. Tschermaks Mineral. Petrogr. Mitt. 14, 55-59.

Makovicky, E. \& BALIĆ-ŽUnić, T. (1998): New measure of distortion for coordination polyhedra. Acta Crystallogr. B54, 766-773.

\& Makovicky, M. (1978): Representation of compositions in the bismuthinite-aikinite series. Can. Mineral. 16, 405-409.

Topa, D. \& BALIĆ-Žunić, T. (2001): The crystal structure of paarite, the newly discovered $56 \AA$ derivative of the bismuthinite-aikinite solid-solution series. Can. Mineral. 39, 1377-1382.

Mozgova, N.N., Nenasheva, S.N., Chistyakova, N.I., Mogilevkin, S.B. \& Sivtsov, A.V. (1990): Compositional fields of minerals in the bismuthinite-aikinite series. Neues Jahrb. Mineral., Monatsh., 35-45.

Mumme, W.G. (1975): The crystal structure of krupkaite, $\mathrm{CuPbBi}_{3} \mathrm{~S}_{6}$, from the Juno mine at Tennant Creek, Northern Territory, Australia. Am. Mineral. 60, 300-308.

\& WatTs, J.A. (1976): Pekoite, $\mathrm{CuPbBi}_{11} \mathrm{~S}_{18}$, a new member of the bismuthinite-aikinite mineral series: its crystal structure and relationship with naturally- and synthetically-formed members. Can. Mineral. 14, 322-333.

Welin, E. \& Wuensch, B.J. (1976): Crystal chemistry and proposed nomenclature for sulfosalts intermediate in the system bismuthinite-aikinite $\left(\mathrm{Bi}_{2} \mathrm{~S}_{3}-\right.$ $\mathrm{CuPbBiS}_{3}$ ). Am. Mineral. 61, 15-20.

OHMASA, M. \& NowACKI, W. (1970a): Note on the space group and on the structure of aikinite derivatives. Neues Jahrb. Mineral., Monatsh., 158-162. 
$\&$

(1970b): A redetermination of the crystal structure of aikinite $\left(\mathrm{BiS}_{2} \mathrm{Cu}(\mathrm{IV}) \mathrm{Pb}(\mathrm{VII})\right) . Z$. Kristallogr. 132, 71-86.

PRING, A. (1989): Structural disorder in aikinite and krupkaite. Am. Mineral. 74, 250-255.

(1995): Annealing of synthetic hammarite, $\mathrm{Cu}_{2} \mathrm{~Pb}_{2} \mathrm{Bi}_{4} \mathrm{~S}_{9}$, and the nature of cation-ordering processes in the bismuthinite-aikinite series. Am. Mineral. 80, 11661173.

SyneČEK, V. \& HybleR, J. (1974): The crystal structure of krupkaite, $\mathrm{CuPbBi}_{3} \mathrm{~S}_{6}$, and of gladite, $\mathrm{CuPbBi}_{5} \mathrm{~S}_{9}$, and the classification of superstructures in the bismuthiniteaikinite group. Neues Jahrb. Mineral., Monatsh., 541-560.

Thalhammer, O.A.R., Stumpfl, E.F. \& Jahoda, R. (1989): The Mittersill scheelite deposit, Austria. Econ. Geol. 84, 1153-1171.
ToPA, D., BALIĆ-Žunić, T., MAKovicky, E. (2000): The crystal structure of $\mathrm{Cu}_{1.6} \mathrm{~Pb}_{1.6} \mathrm{Bi}_{6.4} \mathrm{~S}_{12}$, a new $44.8 \AA$ derivative of the bismuthinite-aikinite solid-solution series. Can. Mineral. 38, 611-616.

MaKovicky, E. \& PAAR, W. (2002): Composition ranges and exsolution pairs for the members of the bismuthinite-aikinite series from Felbertal, Austria. Can. Mineral. 40, 849-869.

Welin, E. (1966): Notes on the mineralogy of Sweden. 5. Bismuth-bearing sulphosalts from Gladhammar, a revision. Arkiv för Mineralogi och Geologi 4, 377-386.

ŽÁk, L, Syneček, V. \& Hybler, J. (1975): Krupkaite, $\mathrm{CuPbBi}_{3} \mathrm{~S}_{6}$, a new mineral of the bismuthinite-aikinite group. Neues Jahrb. Mineral., Monatsh., 533-541.

Received February 1, 2002, revised manuscript accepted July 11, 2002. 